\title{
Allelopathic Activities of Three Emergent Macrophytes on Several Monospecific Cyanobacterial Species and Natural Phytoplankton Assemblages
}

\author{
Sheng-hua Zhang'*, Li Guo², Jin-yan Cao', Jun-jun Chang ${ }^{1}$ \\ 'Research Institute of Engineering and Technology, Yunnan University, Kunming, 650091, China \\ ${ }^{2}$ Hubei Environmental Monitoring Central Station, Wuhan, 430072, China
}

Received: 5 May 2014

Accepted: 8 July 2014

\begin{abstract}
The extracts of three emergent macrophytes (Acorus calamus, Oenanthe javanica, and Sagittaria sagittifolia) were tested to study their allelopathic activities on unicellular Microcystis aeruginosa, Anabaena flosaquae, Aphanizomenon flosaquae, and natural phytoplankton assemblages. The $72 \mathrm{~h} \mathrm{EC}_{50}$ of the most active extracts were measured. The results demonstrated the obvious species-specific activities of macrophytes on algae. Anabaena flosaquae and Aphanizomenon flosaquae was sensitive to the three macrophytes extracts, while unicellular M. aeruginosa was only sensitive to A. calamus and $O$. javanica extracts under the extracts concentration of $100 \mathrm{mg} \cdot \mathrm{L}^{-1}$. Only the extract of A. calamus roots showed high growth inhibition on the natural phytoplankton assemblages in Dianchi Lake (Microcystis water bloom). The $72 \mathrm{~h} \mathrm{EC}_{50}$ of $A$. calamus roots hexane extract on unicellular $M$. aeruginosa was $13.59 \mathrm{mg} \cdot \mathrm{L}^{-1}$, while that on natural phytoplankton assemblages was $48.75 \mathrm{mg} \cdot \mathrm{L}^{-1}$. These results demonstrated that the growth inhibitory activities of allelochemicals on unicellular M. aeruginosa cannot instead of the efficacies for controlling Microcystis bloom completely. And according to the different sensitivities of Microcystis species, the colonial Microcystis strains or natural Microcystis bloom will be proposed as the target organism when searching for Microcystis bloom control.
\end{abstract}

Keywords: allelopathic activity, emergent macrophytes, Cyanobacterial blooming, natural phytoplankton assemblages

\section{Introduction}

Harmful algal bloom (HAB), often cyanobacteria in fresh water, is a frequent and worldwide occurrence especially as eutrophication of water supplies increases [1]. Environmental and health problems from these water blooms, such as deterioration of water quality, potentially decrease biodiversity [2] and affecting human health

*e-mail: zhangshenghua@yahoo.com through food chains [3], have been documented in many regions due to the production of cyanotoxins [4]. Therefore, control and elimination of cyanobacterial blooms is crucial in the management and mitigation of aquatic ecosystems.

A variety of methods have been proposed for removing and/or inhibiting cyanobacterial blooms, such as allelopathy (allelochemicals) from plants [5-7], chemicals [8], bioreactors [9], coagulation-magnetic separation method [10], and microorganism [11]. Among them, allelopathy 
and allelochemicals of macrophytes are gaining increased concern. Allelopathy may be a useful strategy for macrophytes to reduce biomass of epiphytes and phytoplankton in shallow eutrophic lakes [12, 13]. Allelopathy has been explored for many aquatic macrophytes and proposed as an ecological measure to control the growth of undesired phytoplankton, which is a threat to aquatic ecosystems [14-16]. Many submerged macrophytes, such as Vallisneria spiralis L. [17], Myriophyllum spicatum [14, 18, 19], and Potamogeton species [16] et al., can effectively inhibit the growth of $M$. aeruginosa; in addition, some emergent macrophytes and floating plants can also inhibit the growth of water-bloom algae. It has been reported that Phragmites communis can inhibit $M$. aeruginosa [20]. Zhang et al. [21] also found that Anabaena flos-aquae and M. aeruginosa can be suppressed by Thalia dealbata. Emergent macrophytes is widely used in water ecological restoration; therefore, it is important to find whether emergent macrophytes can be used to control algal blooms. Acorus calamus, Oenanthe javanica, and Sagittaria sagittifolia are emergent macrophytes, usually used in ecological restoration of eutrophic water bodies. To date, research on the algaeinhibiting activities of these three macophytes is rare. In this study, the allelopathic activities of three emergent macrophyte extracts on Microcystis aeruginosa, Anabaena flos-aquae, and Aphanizomenon flos-aquae were explored. The species-specific activities of three macrophyte extracts on several cyanobacterials are discussed. The antialgal effect of extracts on phytoplankton assemblages of Dianchi Lake using a short-term laboratory test was also examined. These results would help elucidate the allelopathic activities of $A$. calamus, O. javanica, and $S$. sagittifolia, and eventually provide insight into the feasibility of using allelopathic activities of macrophytes as algicides for algal bloom control.

\section{Materials and Methods}

\section{Materials}

A. calamus, O. javanica, and S. sagittifolia were collected from a small lake in a suburb of Kunming City, Yunnan Province. O. javanica, S. sagittifolia, and roots of A. calamus were then washed to remove surface-deposited and organic materials, dried at normal ambient temperature in July, then powdered. The cyanobacteria species $M$. aeruginosa (FACHB 905), Anabaena flosaquae (FACHB 245), and Aphanizomenon flosaquae (FACHB 1170) were all obtained from the Freshwater Algae Culture Collection of the Institute of Hydrobiology, the Chinese Academy of Sciences. The natural phytoplankton assemblages, which were dominated by the colonial $M$. aeruginosa, were collected from Dianchi Lake in Yunnan Province.

\section{Cyanobacteria Cultivation}

All three cyanobacteria species were pre-cultivated in BG-11 medium. Prior to the initiation of the experiments, the three cyanobacteria species were added to $500 \mathrm{~mL}$ sterilized flasks filled with $200 \mathrm{~mL}$ BG-11 medium and then placed in an incubator using a light intensity of $47.5 \mu \mathrm{mol}$ photons $\mathrm{m}^{-2} \cdot \mathrm{s}^{-1}$ at $25 \pm 2^{\circ} \mathrm{C}$ and photoperiod $14 \mathrm{~L}: 10 \mathrm{D}$ for seven days. Some BG-11medium was also added to the natural phytoplankton assemblages and cultured under the same conditions for seven days for proper acclimation. The algae were shaken three times every day and the bacterial biomass in the cultures was negligible.

\section{Macrophyte Extract Preparation}

$10 \mathrm{~g}$ of powdered plant materials (O. javanica, S. sagittifolia and roots of $A$. calamus) were placed into a flask containing $300 \mathrm{~mL}$ hexane, ethyl acetate and ethanol solution, respectively. The flasks were covered to prevent evaporation and vibrated for $72 \mathrm{~h}$ at room temperature. After 72 $\mathrm{h}$ the solvent was filtered with filter paper to remove the insoluble residue, and then was further removed from the extract in vacuum to give hexane extracts, EtOAC extracts and $\mathrm{EtOH}$ extracts for each plant.

\section{Individual Macrophyte Extracts on Monospecific Species Algae}

The growth inhibition of three cyanobacterial species was performed using the ISO 8692 method [22] with some modifications as described by Xian et al. [17]. Sterilized $100 \mathrm{~mL}$ Erlenmeyer flasks were filled with $35 \mathrm{~mL}$ BG-11 medium and $5 \mathrm{~mL}$ M. aeruginosa, Anabaena flosaquae, or Aphanizomenon flosaquae, and the initial absorbance of these three species of microalgae suspension to 0.15 ( $M$. aeruginosa OD650nm, Anabaena flosaquae OD750nm, Aphanizomenon flosaquae OD663nm). Then the extracts of $O$. javanica, S. sagittifolia or roots of $A$. calamus, which was dissolved into dimethyl sulfoxide (DMSO) firstly, added in the Erlenmeyer flasks to attain $100 \mathrm{mg} \cdot \mathrm{L}^{-1}$ for bioassay of individual macrophyte extracts on monospecific species and $5,10,20,30,50,70 \mathrm{mg} \cdot \mathrm{L}^{-1}$ extract concentrations for the $72 \mathrm{~h} \mathrm{EC}_{50}$ experiments. Highest DMSO levels in the test flasks did not exceed $0.20 \%(\mathrm{v} / \mathrm{v})$. The control groups were prepared only with DMSO. Each experiment included triplicate treatments and the experiments were repeated twice. The algae were cultivated for 3 days at $25^{\circ} \mathrm{C}$ with irradiance $47.5 \mu \mathrm{mol}$ photons $\mathrm{m}^{-2} \cdot \mathrm{s}^{-1}$ at $14: 10$ $\mathrm{L} / \mathrm{D}$ cycle. The growth inhibition percentage for specific tested substance concentration was calculated compared to the control group through chlorophyll a measure using the colorimetric method [23].

\section{Individual Macrophyte Extracts on Natural Phytoplankton Assemblages}

Sterilized flasks were filled with $30 \mathrm{~mL}$ of new BG-11 medium and $10 \mathrm{~mL}$ of plankton assemblages, then the three macrophyte extracts (dissolved in DMSO) were added to make the concentrations $5,10,20,50,70,100 \mathrm{mg} \cdot \mathrm{L}^{-1}$, respectively. Highest DMSO level in the test flasks did not exceed $0.20 \%(\mathrm{v} / \mathrm{v})$. The control groups were prepared only 
with DMSO. All experiments were conducted in triplicate, and the cultural conditions were the same as those mentioned above. During the experiments, a certain amount of microalgae suspension was collected from each flask every other day to measure the contents of chlorophyll a using the colorimetric method.

\section{Statistics}

When algal growth was significantly inhibited, the effective concentration causing a 50\% inhibitory response at $72 \mathrm{hrs}\left(\mathrm{EC}_{50}\right)$ was estimated with logistic fitting.

All the control and treatments were replicated thrice. Statistical differences between the control and treatments were tested using Independent-Samples T-test and One-way ANOVA with SPSS software (13.0) (SPSS, USA) at 95\% confidence level. The normality of data in different groups was tested through Shapiro-Wilk test before statistics.

\section{Results}

\section{Allelopathic Activities of Individual Macrophyte Extracts on Monospecific Species}

Fig. 1 showed that all six extracts of $A$. calamus and $O$. javanica inhibited the growth of $M$. aeruginosa to a certain extent, the differences in $M$. aeruginosa Chl-a values between the control and the treatments were evident $(p<0.05)$. Compared with the control, all the hexane extracts, EtOAC extracts, and EtOH extracts of S. sagittifolia did not show obvious inhibitory effects on $M$. aeruginosa. The maximal growth inhibition was achieved at the EtOH extracts of all three $O$. javanica extracts with the $94 \%$ ratio. The inhibiting ratio of three $A$. calamus extracts was $90 \%$ for both hexane extracts and EtOAC extracts, and $92 \%$ for EtOH extracts.

Fig. 2 shows that almost all of the extracts of $S$. sagittifolia, O. javanica, and A. calamus can inhibit the growth of Aphanizomenon flosaquae except for the EtOAC extracts of $O$. javanica, which simulate the growth of

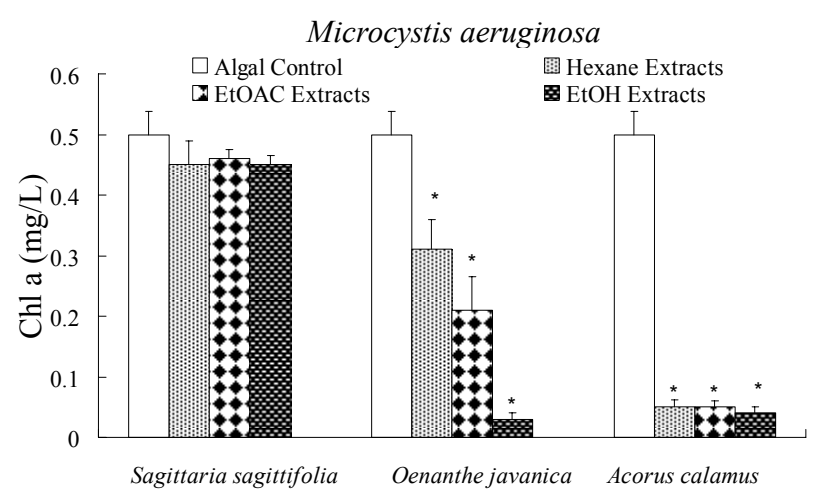

Fig. 1. Allelopathic activities of three emergent macrophyte extracts (S. sagittifolia, O. javanica, and A. calamus) on the growth of $M$. aeruginosa under the concentration of $100 \mathrm{mg} \cdot \mathrm{L}^{-1}$. *Compared with the control, $\mathrm{p}<0.05$

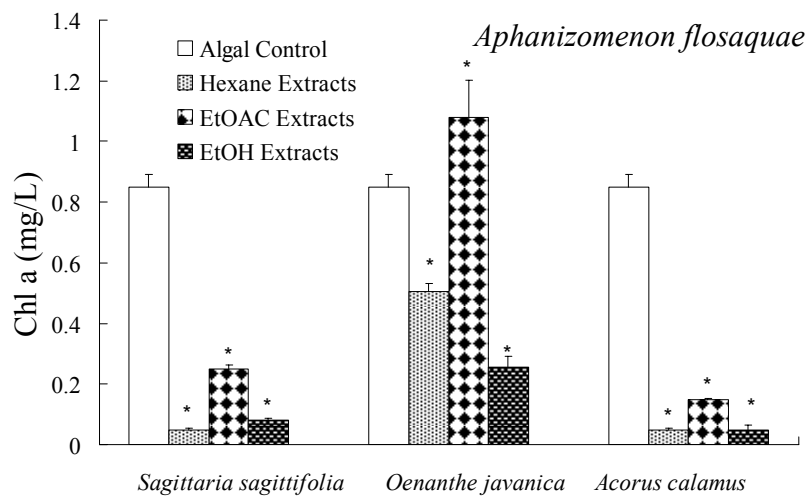

Fig. 2. Allelopathic activities of three emergent macrophyte extracts (S. sagittifolia, O. javanica, and A. calamus) on the growth of Aphanizomenon flosaquae under the concentration of $100 \mathrm{mg} \cdot \mathrm{L}^{-1}$.

*Compared with the control, $\mathrm{p}<0.05$

Aphanizomenon flosaquae inversely. Among them, the inhibition ratio was above $94 \%$ for hexane extracts of $S$. sagittifolia, which was similar to the hexane and EtOH extracts of $A$. calamus. And as Fig. 3 shows, all of the EtOH extracts of three emergent macrophytes showed higher inhibitory activities on Anabaena flosaquae. The hexane extracts of $S$. sagittifolia and hexane and EtOAC extracts of $A$. calamus also achieved a high inhibitory ratio.

\section{Allelopathic Activities of Individual Macrophyte Extracts on Natural Phytoplankton Assemblages}

Fig. 4 shows that the extract can inhibit the growth of phytoplankton assemblages under the concentration of 100 $\mathrm{mg} \cdot \mathrm{L}^{-1}$. Compared with the controls, the chlorophyll a contents of the natural phytoplankton assemblages decreased significantly after $72 \mathrm{~h}$ treatment. The inhibitory ratio of the four effective extracts reached $28.9 \%$ for hexane extracts of S. sagittifolia, $91.4 \%, 89.5 \%$, and $92.1 \%$ for hexane, EtOAC, and EtOH extracts of $A$. calamus roots, respectively.

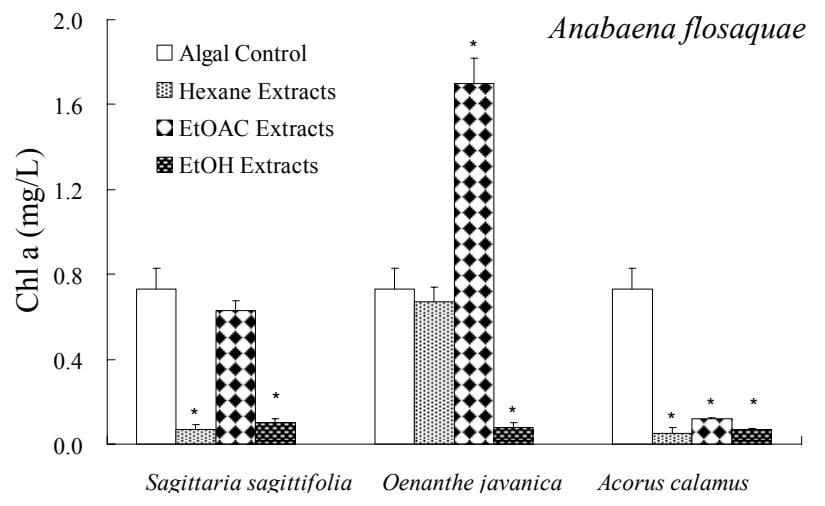

Fig. 3. Allelopathic activities of three emergent macrophyte extracts ( $S$. sagittifolia, O. javanica, and A. calamus) on the growth of Anabaena flosaquae under the concentration of 100 $\mathrm{mg} \cdot \mathrm{L}^{-1}$. ${ }^{*}$ Compared with the control, $\mathrm{p}<0.05$. 


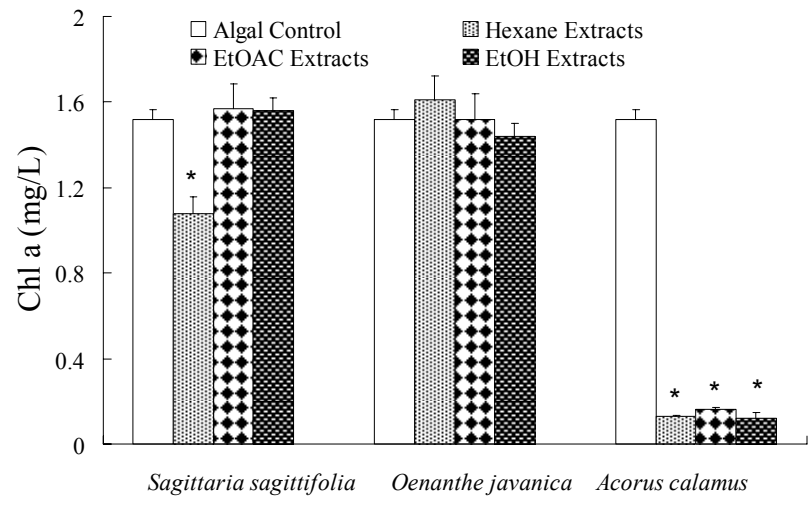

Fig. 4. Allelopathic activities of three emergent macrophyte extracts (S. sagittifolia, O. javanica, and A. calamus) on the growth of natural phytoplankton assemblages from Dianchi Lake under the concentration of $100 \mathrm{mg} \cdot \mathrm{L}^{-1}$.

$*$ Compared with the control, $\mathrm{p}<0.05$.

Effects of Macrophyte Extract Concentrations on Cyanobacteria Species and Natural Phytoplankton Assemblages

Based on the results of individual macrophyte extracts on monospecific species and natural phytoplankton assemblages, some extracts that have higher algal inhibition activities were choosed to measure their $\mathrm{EC}_{50}$ for evaluating the antialgal efficacies. The $72 \mathrm{~h} 50 \%$ growth inhibition concentration $\left(\mathrm{EC}_{50} \mathrm{mg} \cdot \mathrm{L}^{-1}\right)$ of macrophyte extracts on three cyanobacteria species was shown in Table 1 . As for $M$. aeruginosia, the lowest $72 \mathrm{~h} \mathrm{EC}{ }_{50}$ was $9.23 \mathrm{mg} \cdot \mathrm{L}^{-1}$ of $\mathrm{EtOH}$ extracts of $O$. javanica. The maximal inhibition of Anabaena flosaque was achieved in hexane extracts of $S$. sagittifolia with the $\mathrm{EC}_{50}$ of $12.38 \mathrm{mg} \cdot \mathrm{L}^{-1}$. As for Aphanizomenon flosaquae, the $\mathrm{EC}_{50}$ of $S$. sagittifolia hexane extract and $A$. calamus hexane extract was 13.57 and $14.87 \mathrm{mg} \cdot \mathrm{L}^{-1}$, respectively. The growth of natural phytoplankton assemblages was only inhibited by $A$. calamus extracts, and the $\mathrm{EC}_{50}$ of hexane extracts was $48.75 \mathrm{mg} \cdot \mathrm{L}^{-1}$.

\section{Discussion}

A. calamus, O. javanica, and S. sagittifolia are emergent macrophytes usually used in ecological restoration of eutrophic water bodies. However, the allelopthic activities of S. sagittifolia, O. javanica, and A. calamus on M. aeruginosa, Anabaena flosaquae, and Aphanizomenon flosaquae are seldom reported. The growth inhibition of M. aeruginosa by the extracts from plants has been reported before. The extracts with different solvents from three compositae plants have been demonstrated as having inhibitory effects on cyanobacterium M. aeruginosa [24]. The Thalia dealbata roots aqueous extract can significantly inhibit the growth of M. aeruginosa [21]. And in our previous studies the growth of M. aeruginosa was inhibited by the extracts from Potamogeton species [6]. Our present study found the allelopathic potential of A. calamus, O. javanica, and $S$.
Table 1 . The $72 \mathrm{~h} 50 \%$ growth inhibition concentration $\left(\mathrm{EC}_{50}\right.$ $\left.\mathrm{mg} \cdot \mathrm{L}^{-1}\right)$ and equations of the relationships between extracts concentration and algal inhibition ratio of three cyanobacteria species after incubation.

\begin{tabular}{|c|c|c|c|}
\hline Macrophytes & $\begin{array}{c}\text { Extraction } \\
\text { solvent }\end{array}$ & Algae & $\begin{array}{c}\mathrm{EC}_{50} \\
\left(\mathrm{mg} \cdot \mathrm{L}^{-1}\right)\end{array}$ \\
\hline \multirow{4}{*}{ O. javanica } & EtOH & Microcystis aeruginosa & 9.23 \\
\cline { 2 - 4 } & EtOH & Anabaena flosaquae & 23.69 \\
\hline \multirow{4}{*}{$\begin{array}{c}\text { S. sagittifolia } \\
\text { A. calamus } \\
\text { root }\end{array}$} & Hexane & $\begin{array}{c}\text { Aphanizomenon } \\
\text { flosaquae }\end{array}$ & 13.57 \\
\cline { 2 - 4 } & Hexane & Anabaena flosaquae & 12.38 \\
\cline { 2 - 4 } & Hexane & Microcystis aeruginosa & 13.59 \\
\cline { 2 - 4 } & Hexane & $\begin{array}{c}\text { Aphanizomenon } \\
\text { flosaquae }\end{array}$ & 14.87 \\
\cline { 2 - 4 } & Anabaena flosaquae & 19.73 \\
\hline \multirow{2}{*}{\begin{tabular}{c} 
assemblages \\
\hline
\end{tabular}} & 48.75 \\
\hline
\end{tabular}

sagittifolia on the growth inhibition of cyanobacteria. The three emergent macrophytes showed obvious growth inhibition on Aphanizomenon flosaquae and Anabaena flosaquae, while only extracts of A. calamus and $O$. javanica inhibited the growth of $M$. aeruginosa under the concentration of $100 \mathrm{mg} \cdot \mathrm{L}^{-1}$.

Compared with M. aeruginosa, the growth inhibition of Aphanizomenon flosaquae and Anabaena flosaquae by macrophytes is not reported so much. Zhang et al. [21] reported that the $T$. dealbata roots' aqueous extract significantly inhibited the growth of Anabaena flosaquae, and the PSII activity of Aphanizomenon flos-aquae was significantly decreased by Ceratophyllum demersum [18]. In this study, all the extracts from S. sagittifolia, O. javanica, and A. calamus (except for the Ethyl acetate extracts of S. sagittifolia, and $O$. javanica) showed obvious growth inhibition of Anabaena flosaquae and Aphanizomenon flosaquae. The hexane and ethanol extracts have high antialgal activities, while the EtOAC extracts of $O$. javanica increase the Chla content of algae inversely. These results probably indicated that the antialgal constituents in $O$. javanica belong to compounds with no and weak polarity or strong polarity, and the compounds with mediated polarity extracts own weaker antialgal ability, which even stimulated the Chl- $a$ contents of Anabaena flosaquae and Aphanizomenon flosaquae.

Many studies exhibit the allelopathic effects of macrophytes on phytoplankton appear to be species-specific. Mulderij [25] showed that the sensitivity of cyanobacteria to Stratiotes water was not higher than that of other phytoplankton strains, and within cyanobacteria the toxic strain was more sensitive than the non-toxic one. Körner and Nicklisch [18] found that members of the Oscillatoriales and $M$. aeruginosa were more sensitive to the allelopathy of Myriophyllum spicatum than the cyanobacterium Aphamzomenon flos-aquae. Planas et al. [26] found that 
Cyanophyta were more sensitive to phenolic extracts of $M$. spicatum than chlorophyta. The results of Nakai [14] indicated that in subsequent initial addition of assays using Potamogeton oxyphyllus, the growth of M. aeruginosa was inhibited significantly while the growth inhibition of Aphanizomenon flos-aquae was not observed. Selenastrum capricornutum and $M$. aeruginosa have different sensitivities to exudates from two Potamogeton species [6]. In our study, the growth of Anabaena flosaquae and Aphanizomenon flosaquae was inhibited by most of the extracts of three emergent macrophytes except EtOAC extracts from $O$. javanica and $S$. sagittifolia, which increased the algal Chl-a contents inversely. Anabaena flosaquae and Aphanizomenon flosaquae were sensitive to the three macrophyte extracts while $M$. aeruginosa was only sensitive to $A$. calamus and $O$. javanica extracts under the extracts concentration of $100 \mathrm{mg} \cdot \mathrm{L}^{-1}$.

The control of water-bloom organisms has become an important subject of environmental water management, and screening of biologically active compounds from macrophytes has been paid considerable attention. So far, there has been much research about algae species in artificial culture, but little has been reported on the natural phytoplankton assemblages controlling. In the present study we tested three aquatic plants for antialgal efficacy. Although some of the extracts are capable of inhibiting cyanobacteria in experimental conditions, we wanted to test whether they also have the potential to inhibit natural phytoplankton assemblages in lake water. As such, we collected the phytoplankton assemblages from eutrophic lake water and tested their response to the 9 extracts from $O$. javanica, S. sagittifolia, and roots of $A$. calamus. As far as we know, it is the first report evaluating the crude extracts of these three macrophytes against natural phytoplankton assemblages in Dianchi Lake.

The results showed the Chl- $a$ contents of phytoplankton assemblages from Dianchi Lake decreased significantly when treated with the three extracts from A. calamus roots, which indicated that $A$. calamus root extracts stress led to a decrease in the phytoplankton biomass. This result is accordance with the findings of natural phytoplankton assemblages from Chaohu Lake in Anhui Province, which were dominated by the genera Microcystis and Anabaena, and were inhibited by the $T$. dealbata roots aqueous extracts [21]. Colonial M. aeruginosa is the main bloom species in the phytoplankton assemblages from Dianchi Lake in summer [27]. The growth of $M$. aeruginosa (unicellular) was inhibited by the extracts from $O$. javanica and $A$. calamus roots (Fig. 1), while the growth of natural phytoplankton assemblages from Dianchi Lake was only inhibited by the extracts from $A$. calamus roots (Fig. 1). That is to say both the unicellular and colonial Microcystis strains were inhibited by the extracts from $A$. calamus roots, and unicellular $M$. aeruginosa was more sensitive than the colonial strain. This result is consistent with the results of Park et al. [5], who reported that growth inhibition of unicellular $M$. aeruginosa was much higher than that of colonial $M$. aeruginosa (prevalent in Microcystis water bloom) when treated with rice hull crude extract. It has been reported that colonial Microcystis strains have strong resistance to stress
[28] and endure stress better than the unicellular strains [29]. Based on these findings, the different sensitivities of $M$. aeruginosa and nature phytoplankton assemblages to the extracts from $O$. javanica may correlates positively with the colony size of Microcystis strains.

In previous studies, the $72 \mathrm{~h} \mathrm{EC}$ 50 of many allelochemicals have been measured, such as ethyl-2-methylacetoacetate $\left(0.5 \mathrm{mg} \cdot \mathrm{L}^{-1}\right)$ [20], pyrogallic acid $\left(2.97 \mathrm{mg} \cdot \mathrm{L}^{-1}\right)$ [19], gallic acid $\left(5.5 \mathrm{mg} \cdot \mathrm{L}^{-1}\right)$ [30], the ethyl acetate extract from Hydrilla verticillata $\left(1,280 \mathrm{mg} \cdot \mathrm{L}^{-1}\right)$ [7], and the chloroform extracts from extracts of Phellodendron amurense (173.3 $\left.\mathrm{mg} \cdot \mathrm{L}^{-1}\right)$ [31]. Among them, most of the solo compound exhibits the lower $\mathrm{EC}_{50}$, while the $\mathrm{EC}_{50}$ of crude extracts are higher. Compared with the H. verticillata [7], the extracts from $O$. javanica, S. sagittifolia, and $A$. calamus showed lower $\mathrm{EC}_{50}$ values (Table 1) on Anabaena flosaquae. And although the $72 \mathrm{~h} \mathrm{EC}_{50}$ of hexane extract from $A$. calamus roots on $M$. aeruginosa was $13.59 \mathrm{mg} \cdot \mathrm{L}^{-1}$, the $\mathrm{EC}_{50}$ on natural phytoplankton assemblages was $48.75 \mathrm{mg} \cdot \mathrm{L}^{-1}$. The result demonstrated that the growth inhibitory activities of allelochemicals on unicellular $M$. aeruginosa could not instead of the efficacies for controlling Microcystis bloom completely. And according to the different sensitivities of Microcystis species, the colonial Microcystis strains or natural Microcystis bloom will be considered as the target organism when studing allelpoathy between macrophytes and Microcystis strains or searching algicides for Microcystis bloom control.

Our results show that the extracts from three emergent macrophytes (A. calamus, O. javanica, and S. sagittifolia) can inhibit the growth of cyanobacteria. And the effect of extracts on algae exhibit species-specific activities obviously. As for M. aeruginosia, the lowest $72 \mathrm{~h} \mathrm{EC}_{50}$ was $9.23 \mathrm{mg}$ $/ \mathrm{L}$ of EtOH extracts of $O$. jacanica. The maximal inhibition of Anabaena flosaque was achieved in hexane extracts of $S$. sagittifolia with the $\mathrm{EC}_{50}$ of $12.38 \mathrm{mg} / \mathrm{L}$. As for Aphanizomenon flosaquae, the $\mathrm{EC}_{50}$ of $S$. sagittifolia hexane extract and $A$. calamus hexane extract was 13.57 and $14.87 \mathrm{mg} / \mathrm{L}$, respectively. The growth of natural phytoplankton assemblages was only inhibited by $A$. calamus root extracts, and the $\mathrm{EC}_{50}$ of hexane extracts was $48.75 \mathrm{mg} / \mathrm{L}$. These results demonstrated that the growth inhibitory activities of allelochemicals on unicellular $M$. aeruginosa cannot instead of the efficacies for controlling Microcystis bloom completely. And according to the different sensitivities of Microcystis species, the colonial Microcystis strains or natural Microcystis bloom will be proposed as the target organism when s for Microcystis bloom control.

\section{Acknowledgements}

This work was supported by the National Science and Technology Pillar Program during the Twelfth Five-year Plan Period (2013BAB06B03), grants from the National Science Fund of China (51008265, 51468066), and the Program for Science Research of Yunnan Enducational Committee (2013Y352). 


\section{References}

1. O'NEIL J. M., DAVIS T.W., BURFORD M. A., GOBLER C.J. The rise of harmful cyanobacteria blooms: the potential roles of eutrophication and climate change, Harmful Algae 14, 313, 2012.

2. DAVIS J.R., KOOP K. Eutrophication in Australian rivers, reservoirs and estuaries - A southern hemisphere perspective on the science and its implications, Hydrobiol. 559, 23, 2006.

3. SONG L.R. CHEN W., PENG L., WAN N., GAN N.Q., ZHANG X.M. Distribution and bioaccumulation of microcystins in water columns: A systematic investigation into the environmental fate and the risks associated with microcystins in Meiliang Bay, Lake Taihu. Wat. Res. 41, 2853, 2007.

4. AZEVEDO S.M., CARMICHAEL W.W., JOCHIMSEN E.M., RINEHART K.L., LAU S., SHAW G.R., EAGLESHAM G.K. Human intoxication by microcystins during renal dialysis treatment in Caruaru, Brazil. Toxicol. 181-182, 441, 2002.

5. PARK M.H., CHUNG I.M., AHAMAD A., KIM B.H. HWANG S.J. Growth inhibition of unicellular and colonial Microcystis strains (Cyanophyceae) by compounds isolated from rice (Oryza sativa) hulls. Aquat. Bot. 90, 309, 2009.

6. ZHANG S.H., SUN P.S., GE F.J. WU Z.B. Different sensitivities of Selenastrum capricornutum and toxic strain Microcystis aeruginosa to exudates from two Potamogeton species. Pol. J. Environ. Stud. 20, (1), 1359, 2011.

7. ZHANG T.T., HE M., WU A.P., NIE L.W. Inhibitory effects and mechanisms of Hydrilla verticillata (Linn.f.) Royle extracts on freshwater algae. B. Environ. Contam. Tox. 88, 477, 2012.

8. SPENCER D.F., LIOW P.S., LEMBI C.A. Influence of a non-copper algicide on the cyanobacterium, Nostoc spongiaeforme, and the green alga, Hydrodictyon reticulatum, in field and laboratory experiments, Paddy Wat. Environ. 11, 611, 2013

9. WU Y.H., ZHANG S.Q., ZHAO H.J., YANG L.Z. Environmentally benign periphyton bioreactors for controlling cyanobacterial growth, Bioresource Technol. 101, 9681, 2010.

10. LIU D., WANG P., WEI G., DONG E., HUI F. Removal of algal blooms from freshwater by the coagulation - magnetic separation method, Environ. Sci. Pollut. Res. 20, (1), 60, 2013.

11. KONG Y., XU X. ZHU L., MIAO L. Control of the harmful alga Microcystis aeruginosa and absorption of nitrogen and phosphorus by Candida utilis. Appl. Biochem. Biotechnol. 169, 88, 2013.

12. ERHARD D., GROSS E.M. Allelopathic activity of Elodea canadensis and Elodea nuttallii against epiphytes and phytoplankton. Aquat. Bot. 85, 203, 2006.

13. MULDERIJ G, SMOLDERS A.J.P, VAN DONK E. Allelopathic effect of the aquatic macrophyte, Stratiotes aloides, on natural phytoplankton. Freshwater Biol. 51, 554, 2006.

14. NAKAI S., INOUE Y., HOSOMI M., MURAKAMI A. Growth inhibition of blue-green algae by allelopathic effects of macrophytes. Wat. Sci. Tech. 39, 47, 1999.

15. JOO S., JUNG J.Y., PARK S. Inhibition of submerged macrophytes on phytoplankton I. Field evidence for sub- merged macrophyte inhibition on phytoplankton biomass, Korean J. Limnol. 40, 511, 2007.

16. 16. ZHANG S.H., CHENG S.P., WANG H.Q., HE F., WU Z.B. Allelopathic interactions between the Potamogeton spp and toxic cyanobacteria (Microcystis aeruginosa). Allelopathy J. 23, 379, 2009.

17. XIAN Q., CHEN H., LIU H., ZOU H., YIN D. Isolation and identification of antialgal compounds from the leaves of Vallisneria spiralis L. by activity-guided fractionation. Environ. Sci. Pollut. Res. 13, 233, 2006.

18. KÖRNER S., NICKLISH A. Allelopathic growth inhibition of selected phytoplankton species by submerged macrophytes. J. Phycol. 38, 862, 2002.

19. ZHU J., LIU B., WANG J., GAO Y., WU Z. Study on the mechanism of allelopathic influence on cyanobacteria and chlorophytes by submerged macrophyte (Myriophyllum spicatum) and its secretion. Aquat. Toxicol. 98, 196, 2010.

20. LI F.M., HU H.Y. Isolation and characterization of a novel antialgal allelochemical from Phragmites communis. Appl. Environ. Microbiol. 71, 6545, 2005.

21. ZHANG T.T., WANG, L.L., HE Z.X., ZHANG D. Growth inhibition and biochemical changes of cyanobacteria induced by emergent macrophyte Thalia dealbata roots. Biochem. Syst. Ecol. 39, 88, 2011.

22. ISO 8692. Water quality - Fresh water algal growth inhibition test with Scenedesmus subspicatus and Selenastrum capricornutum, 1989.

23. EATON A.D., CLESCERI L.S., RICE E.W., GREENVERG A.E. Standard Methods for the Examination of Water and Wastewater, $21^{\text {st }}$ ed. American Public Health Association, Washington, DC., 2005.

24. NI L.X., HAO X.Y., LI S.Y., CHEN S.J., REN G.X., ZHU L. Inhibitory effects of the extracts with different solvents from three compositae plants on cyanobacterium Microcystis aeruginosas. Sci. China-Chem. 54, 1123, 2011.

25. MULDERIJ G., MOOIJ W.M., SMOLDERS A.J.P., VON DONK E. Allelopathic inhibition of phytoplankton by exudates from Stratiotes aloides. Aquat. Bot. 82, 284, 2005.

26. PLANAS D., SARHAN F., DUBE L., GODMAIRE H., CADIEUX C. Ecological significance of phenolic compounds of Myriophyllum spicatum. Verh. Internat. Verein. Limnol. 21, 1492, 1981.

27. SHENG H. Studies on physiological and biochemical responses to and competition for phosphorus in two bloomforming cyanobacteria. Doctoral Dissertation of Institute of Hydrobiology, The Chinese Academy of Sciences, 2007.

28. WU Z.X., GAN N.Q., HUANG Q., Song L.R. Response of Microcystis to copper stress - Do phenotypes of Microcystis make a difference in stress tolerance? Environ. Pollut. 147, 324, 2007.

29. SHEN H., SONG L.R. Comparative studies on physiological responses to phosphorus in two phenotypes of bloomforming Microcystis. Hydrobiol. 592, 475, 2007.

30. WANG H.Q., WU Z.B., ZHANG S.H., CHENG S.P., HE F., LIANG W. Relationship between the allelopathic activity and molecular structure of hydroxyl derivatives of benzoic acid and their effects on cyanobacterium Microcystis aeruginosa. Allelopathy J. 22, 205, 2008.

31. YI Y.L., LEI Y., YIN Y.B., ZHANG H.Y., WANG G.X. The antialgal activity of 40 medicinal plants against Microcystis aeruginosa. J. Appl. Phycol., 24, 847, 2012. 